\title{
STUDIES ON HEAT RESISTANCE
}

\section{Sporulation of Bacillus cereus in Some Synthetic Media and the Heat Resistance of the Spores Produced ${ }^{1}$}

\author{
O. B. WILLIAMS AND O. F. HARPER, JR. \\ Department of Bacteriology, University of Texas, Austin, Texas
}

Received for publication February 2, 1951

Synthetic media would provide a valuable tool for an evaluation of the significance in spore resistance of changes in the nutritive environment if spores could be produced in quantity in such media. It is not difficult to formulate chemically defined media for the growth of most, if not for all, of the aerobic sporeforming species, but few of such media will support spore formation. Williams (1929) was unable to obtain spores in a number of synthetic media with a strain of Bacillus subtilis, and was forced to use peptone water as the basic medium for the production of spores for heat resistance testing. Roberts (1934) later was able to devise a synthetic medium in which a significant percentage of sporulation was obtained with the same B. subtilis strain. Brewer, McCullough, Mills, Roessler, Herbst, and Howe (1946) developed a synthetic medium for Bacillus anthracis in which sporulation was abundant, and Foster and Heiligman (1949) were successful in formulating a chemically defined medium in which Bacillus cereus would sporulate. F. L. Davis, working in association with the senior author, has been able recently to obtain good spore crops in certain synthetic media with Bacillus globigii. ${ }^{2}$

It seems to be somewhat more difficult to devise a synthetic medium for the anaerobic spore-bearing rods, and consequently less is known about the sporulation behavior of members of the Clostridium genus in such media. However, the same situation as to growth and spore formation prevails as with the aerobic sporulating rods, if experience with Clostridium botulinum is characteristic. The synthetic medium developed for toxin formation by this organism (Roessler and Brewer, 1950) affords very slight or no sporulation although growth and toxin formation occur readily.

The usual experience that growth is considerably less luxuriant in synthetic media than in complex media means that even a high percentage of sporulation may not mean a very large number of spores. The present investigation was undertaken to determine whether spores could be produced in synthetic media in sufficient number to permit readily of resistance testing.

The organisms selected for study were two strains of $B$. cereus. One of these, no. 3, was originally isolated as a contaminant from a flask of Roessler and

\footnotetext{
1 The research here reported has been undertaken in co-operation with the Biological Department, Chemical Corps, under Contract W18-064-CM 243. The views or conclusions contained in this report are those of the authors. They are not to be construed as necessarily reflecting the views or having the endorsement of the Department of the Army.

- Bacillus globigii is a variety of Bacillus subtilis according to the classification scheme of Bergey's Manual of Determinative Bacteriology.
} 
Brewer medium in which it was observed to sporulate well. The other strain, no. 6, was taken from the stock culture collection. It also was found to give a high percentage of sporulation in the medium.

All glassware used in the preparation and storage of synthetic media, and for the growth of the organisms, was cleaned with acid cleaning mixture, rinsed with tap water, distilled water, and finally with triply-distilled water. The chemicals used were the best commercial grade. In instances in which small quantities of a component were required, an appropriate aliquot was added from a solution in triply-distilled water. Glucose was sterilized separately in distilled water by steam under pressure, and cysteine was sterilized by filtration of a solution. These components were added from sterile solutions to those media in which they appeared. In all other instances sterilization of the complete medium was effected by steam under 15 pounds pressure for 15 minutes. The $\mathrm{pH}$ value of all media was adjusted to 7.0 with either $\mathrm{NaOH}$ or $\mathrm{HCl}$ solution.

TABLE 1

Composition of medium

\begin{tabular}{|c|c|c|c|}
\hline 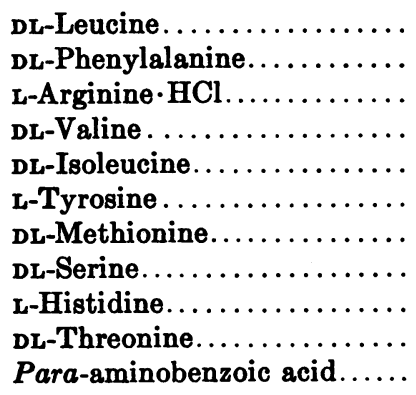 & $\begin{array}{l}0.00083 \mathrm{M} \\
0.00132 \mathrm{M} \\
0.00065 \mathrm{M} \\
0.00083 \mathrm{M} \\
0.0004 \mathrm{M} \\
0.00003 \mathrm{M} \\
0.0002 \mathrm{M} \\
0.001 \mathrm{M} \\
0.00013 \mathrm{M} \\
0.00067 \mathrm{M} \\
0.002 \mu \mathrm{g} / \mathrm{ml}\end{array}$ & 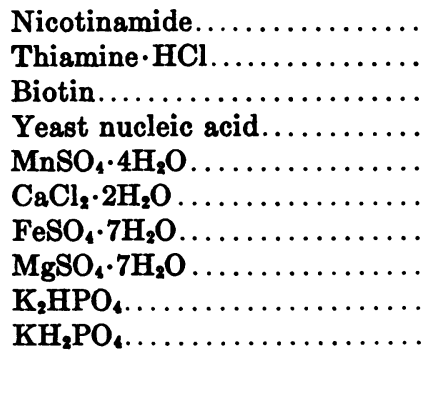 & $\begin{array}{l}0.1 \mu \mathrm{g} / \mathrm{ml} \\
0.02 \mu \mathrm{g} / \mathrm{ml} \\
0.5 \mu \mathrm{g} / \mathrm{ml} \\
0.001 \% \\
0.00001 \mathrm{M} \\
0.00001 \mathrm{M} \\
0.000005 \mathrm{M} \\
0.00002 \mathrm{M} \\
0.0015 \mathrm{M} \\
0.0015 \mathrm{M}\end{array}$ \\
\hline
\end{tabular}

Two lines of attack on the problem of producing spore crops in synthetic media were followed. One consisted of testing individual amino acids for availability of carbon, of nitrogen, and of both carbon and nitrogen, by incorporating the amino acid in 0.05 per cent concentration in a mineral solution with either added ammonium sulfate, or glucose, or with no supplement added. The mineral solution was essentially that described by Stokes and Woodward (1943). The other approach to the problem consisted of simplifying a rather complex synthetic medium similar to that of Roessler and Brewer through the elimination of single components. An early experiment indicated that the Roessler and Brewer medium could be diluted to one-tenth concentration with satisfactory percentage yields, and this was the concentration employed with the synthetic media throughout the work. Media were prepared in 250-ml quantities in 500-ml flasks. The cultures were passed through three tubes of the same medium, and the test flask was inoculated with $0.05 \mathrm{ml}$ of a 3-day culture from the third transplant containing both spores and vegetative cells. Incubation was at $37 \mathrm{C}$ for 10 days, after which the culture was transferred to a glass-stoppered bottle with beads and shaken vigorously by hand. Counts were made to determine the per- 
TABLE 2

Sporulation in synthetic media and heat resistance of the spores produced

\begin{tabular}{|c|c|c|c|c|}
\hline \multirow{2}{*}{ COMPONENT OUTTTED } & \multirow{2}{*}{ strant } & \multirow{2}{*}{ \% SPORES } & \multicolumn{2}{|c|}{$\begin{array}{l}\text { RESISTANCE AT } 99.5 \mathrm{C} \mathrm{I} \\
\text { MINUTES }\end{array}$} \\
\hline & & & Survived & Killed \\
\hline Valine & $\begin{array}{l}6 \\
3\end{array}$ & $\begin{array}{l}\text { No growth } \\
\text { No growth }\end{array}$ & - & \\
\hline Leucine & $\begin{array}{l}6 \\
3\end{array}$ & $\begin{array}{l}85 \\
45\end{array}$ & $\begin{array}{r}18 \\
8\end{array}$ & $\begin{array}{l}20 \\
10\end{array}$ \\
\hline Phenylalanine & $\begin{array}{l}6 \\
\mathbf{3}\end{array}$ & $\begin{array}{l}95 \\
95\end{array}$ & $\begin{array}{r}16 \\
8\end{array}$ & $\begin{array}{l}18 \\
10\end{array}$ \\
\hline Arginine & $\begin{array}{l}6 \\
3\end{array}$ & $\begin{array}{l}90 \\
80\end{array}$ & $\begin{array}{r}18 \\
8\end{array}$ & $\begin{array}{l}20 \\
10\end{array}$ \\
\hline Isoleucine & $\begin{array}{l}6 \\
3\end{array}$ & $\begin{array}{l}100 \\
100\end{array}$ & $\begin{array}{r}16 \\
8\end{array}$ & $\begin{array}{l}18 \\
10\end{array}$ \\
\hline Tyrosine & $\begin{array}{l}6 \\
3\end{array}$ & $\begin{array}{l}85 \\
90\end{array}$ & $\begin{array}{r}18 \\
8\end{array}$ & $\begin{array}{l}20 \\
10\end{array}$ \\
\hline Methionine & $\begin{array}{l}6 \\
3\end{array}$ & $\begin{array}{l}80 \\
70\end{array}$ & $\begin{array}{r}18 \\
8\end{array}$ & $\begin{array}{l}20 \\
10\end{array}$ \\
\hline Threonine & $\begin{array}{l}6 \\
3\end{array}$ & $\begin{array}{r}100 \\
95\end{array}$ & $\begin{array}{r}18 \\
8\end{array}$ & $\begin{array}{l}20 \\
10\end{array}$ \\
\hline Serine & $\begin{array}{l}6 \\
\mathbf{3}\end{array}$ & $\begin{array}{l}95 \\
95\end{array}$ & $\begin{array}{r}18 \\
8\end{array}$ & $\begin{array}{l}20 \\
10\end{array}$ \\
\hline Histidine & $\begin{array}{l}6 \\
3\end{array}$ & $\begin{array}{l}90 \\
90\end{array}$ & $\begin{array}{r}16 \\
6\end{array}$ & $\begin{array}{r}18 \\
8\end{array}$ \\
\hline Biotin & $\begin{array}{l}6 \\
3\end{array}$ & $\begin{array}{l}85 \\
90\end{array}$ & $\begin{array}{r}14 \\
8\end{array}$ & $\begin{array}{l}16 \\
10\end{array}$ \\
\hline Para-aminobenzoic acid & $\begin{array}{l}6 \\
3\end{array}$ & $\begin{array}{l}55 \\
40\end{array}$ & $\begin{array}{r}18 \\
8\end{array}$ & $\begin{array}{l}20 \\
10\end{array}$ \\
\hline Nicotinamide & $\begin{array}{l}6 \\
\mathbf{3}\end{array}$ & $\begin{array}{l}95 \\
95\end{array}$ & $\begin{array}{r}18 \\
6\end{array}$ & $\begin{array}{r}20 \\
8\end{array}$ \\
\hline Thiamine & $\begin{array}{l}6 \\
3\end{array}$ & $\begin{array}{r}85 \\
100\end{array}$ & $\begin{array}{r}18 \\
8\end{array}$ & $\begin{array}{l}20 \\
10\end{array}$ \\
\hline Yeast nucleic acid & $\begin{array}{l}6 \\
3\end{array}$ & $\begin{array}{r}90 \\
100\end{array}$ & $\begin{array}{r}16 \\
4\end{array}$ & $\begin{array}{r}18 \\
6\end{array}$ \\
\hline $\begin{array}{c}\text { Controls } \\
\text { Complete synthetic medium }\end{array}$ & $\begin{array}{l}6 \\
\mathbf{3}\end{array}$ & $\begin{array}{l}95 \\
95\end{array}$ & $\begin{array}{r}18 \\
8\end{array}$ & $\begin{array}{l}20 \\
10\end{array}$ \\
\hline 1\% Albimi C peptone & $\begin{array}{l}6 \\
3\end{array}$ & $\begin{array}{l}55 \\
55\end{array}$ & $\begin{array}{r}18 \\
8\end{array}$ & $\begin{array}{l}20 \\
10\end{array}$ \\
\hline
\end{tabular}


centage of sporulation; the cells were washed twice with tap water, suspended in $\mathbf{M} / 30$ phosphate buffer, and filtered through coarse filter paper to remove clumps. Each suspension was standardized by means of a Petroff-Hausser count to contain 2,000,000 spores per $\mathrm{ml}$, and heat resistance determinations were made according to the multiple tube method of Esty and C. C. Williams (1924) as applied by O. B. Williams (1929). Recovery cultures were made in 1 per cent Albimi peptone $\mathbf{C}$ medium. End points were recorded in the customary manner.

\section{RESULTS}

The nature of the project was such that some information on growth requirements and on the degree of sporulation was developed, even though the experiments were conducted with the objective of determining whether spores could be produced in quantity in synthetic media and what, if any, is the effect of the amino acid composition of the media on resistance. The substances tested individually for availability as a source of carbon, of nitrogen, and of both carbon and nitrogen were L-glutamic acid, DL-aspartic acid, L-alanine, L-cystine, DL-leucine, DL-phenylalanine, L-arginine, DL-isoleucine, L-tryptophan, L-tyrosine, DLmethionine, DL-threonine, DL-serine, DL-histidine, DL-valine, L-lysine, L-proline, hydroxy-L-proline, DL-norleucine, L-cysteine, glycine, and L-asparagine. No one of these alone would serve as a source of either carbon or nitrogen, or both carbon and nitrogen, for either test strain of $B$. cereus.

The basic medium in which both growth and sporulation of each strain took place had the composition given in table 1 . This medium was altered by the omission of a single component, either an amino acid, a growth factor, or the yeast nucleic acid. Growth occurred with each strain except when valine was omitted. Roessler and Brewer (1950) and Blair (1950) likewise failed to obtain growth in the absence of valine with Clostridium botulinum as the test organism. Gladstone (1939) has noted the mutual detoxifying effect of valine and several other amino acids in synthetic media for $B$. anthracis. This amino acid clearly has significance for more than lactobacilli, streptococci, and members of the genus Leuconostoc, for which it has been recorded as essential by Stephenson (1949).

Differences in luxuriance of growth among the different media were noted, but no determinations beyond incidental observation were made. The percentage of sporulation recorded for each organism for each medium tested is based on the average of at least two independent and concordant determinations and is given to the nearest 5 per cent. The control media were 1 per cent Albimi $\mathrm{C}$ peptone water and the complete synthetic medium. The percentage of sporulation and the resistance of the spores produced is presented in table 2 .

\section{DISCUSSION}

The appreciable difference in resistance between the two strains is in accord with the general experience with spores from complex media that different strains of the same species may exhibit considerable differences in resistance. 
Sporulation in the synthetic media tested was generally in higher percentage than in the control medium. Para-aminobenzoic acid appears to have some significance in stimulating cells to enter the spore state since omission of this factor from the medium caused a drop in the percentage of sporulation of each strain. Strain 3 showed also a drop in the percentage of spores in the medium lacking leucine. A difference in the percentage of sporulation in the same medium among strains of the same species has previously been reported by Schmidt (1950).

Observations of the extent of sporulation in relation to the amount of growth were in accord with the experience of Williams (1931) with $B$. subtilis grown in complex media. The peptone water supported the most luxuriant growth.

The sporulation differences between the complex medium and the synthetic media may be a reflection of the influence of factors naturally present in the complex medium, but not in the synthetic media, which are inhibitory to sporulation. Thus Roberts and Baldwin (1942) were able to demonstrate an antisporulation factor in complex media for $B$. subtilis, which was removable with activated charcoal, and Foster, Hardwick, and Guirard (1950) similarly have noted that both growth and sporulation of Bacillus larvae could be enhanced by treatment of the (complex organic) media with activated charcoal or by the incorporation of starch as a component.

The luxuriance of growth and the luxuriance of sporulation clearly were not governing factors in determining the heat resistance of the spores under the conditions of the experiments. No significant differences in resistance were recorded for cultures although differences in luxuriance of growth, and in degree of sporulation, were noted.

\section{SUMMARY}

Spores in adequate quantity for heat resistance testing were produced in chemically defined media by two strains of Bacillus cereus. Resistance was not affected by any one of the amino acids, growth factors, or yeast nucleic acid as nutrients.

Resistance was independent of the luxuriance of growth and of the luxuriance of sporulation.

The test strains did not grow unless valine was present in the medium.

\section{REFERENCES}

BlaIr, E. B. 1950 Observations on bacterial spore formation in synthetic media. M.A. Thesis, University of Texas.

Brewer, C. R., McCullough, W. G., Mills, R. C., Rogssler, W. G., Herbst, E. J., AND HowE, A. F. 1946 Studies on the nutritional requirements of Bacillus anthracis. Arch. Biochem., 10, 65-75.

Esty, J. R., and Williams, C. C. 1924 Heat resistance studies. I. A new method for the determination of heat resistance of bacterial spores. J. Infectious Diseases, 34, 516-528.

Foster, J. W., Hardwick, W. A., and Goirard, Beverly 1950 Antisporulation factors in complex organic media. I. Growth and sporulation studies on Bacillus larvae. J. Bact., 59, 463-470.

Foster, J. W., and Heiligman, Fred 1949 Biochemical factors influencing sporulation in a strain of Bacillus cereus. J. Bact., 57, 639-646. 
Gladstone, G. P. 1939 Interrelationships between amino acids in the nutrition of $B$. anthracis. Brit. J. Exptl. Path., 20, 189-200.

Roberts, J. L. 1934 Endospore formation by Bacillus subtilis in a synthetic medium. Science (N. S.), 79, 432-433.

RoberTs, J. L., AND BALDwin, I. L. 1942 Spore formation by Bacillus subtilis in peptone solutions altered by treatment with activated charcoal. J. Bact., 44, 653-659.

Roessler, W. G., AND BREWER, C. R. 1950 Unpublished data.

Schmid, C. F. 1950 Spore formation by thermophilic flat sour organisms. I. The effect of nutrient concentration and the presence of salts. J. Bact., 60, 205-212.

Stephenson, Marjory 1949 Bacterial metabolism. 3d ed. Longmans, Green and Co., London.

Stokes, J. L., and Woodward, C. R., JR. 1943 Formation of tyrothricin in submerged cultures of Bacillus brevis. J. Bact., 46, 83-88.

Wrlliams, O. B. 1929 The heat resistance of bacterial spores. J. Infectious Diseases, 44, 421-465.

Williams, O. B. 1931 Bacterial endospore formation in media of varying biologic value. Proc. Soc. Exptl. Biol. Med., 28, 615-617. 